\title{
Pelayanan Kepala Sekolah terhadap Tenaga Pendidik di Sekolah Dasar Negeri 01 Benteng Hulu Kecamatan Mempura Kabupaten Siak
}

\author{
MARZUKI \\ Sekolah Tinggi Agama Islam Sulthan Syarif Hasyim siak \\ IRAWATI \\ Universitas Islam Negeri Sulthan Syarif Kasim Riau
}

\begin{abstract}
ABSTRAK
Sesuai dengan judul diatas, Pelayanan kepala sekolah merupakan salah satu faktor yang dapat mendorong sekolah untuk dapat mewujudkan visi, misi, tujuan, dan sasaran sekolah melalui program-program yang dilaksanakan secara terencana dan bertahap. Oleh karena itu kepala sekolah dituntut trampil dalam memimpin agar mampu mengambil keputusan dan prakarsa yang tepat untuk meningkatkan layanan Sekolah. Berdasarkan pokok masalah yang penulis ambil yaitu bagaimana Pelayanan kepala sekolah terhadap tenaga pendidik di sekolah Dasar Negeri 01 Benteng Hulu Kecamatan Mempura Kabupaten Siak dan apa Faktor pendukung dan penghambat pelayanan kepala sekolah Dasar Negeri 01 Benteng Hulu Kecamatan Mempura Kabupaten Siak. Dalam mengumpulkan data menggunakan wawancara, angket dan dokumentasi, populasi disini yaitu kepala sekolah Dasar Negeri 01 dan guru-guru berjumlah 31 orang.

Seorang kepala sekolah dikatakan mampu melaksanakan tugasnya sebagai manejer dapat dikategorikan sebagai berikut yaitu Kepala sekolah melayani Tenaga Pendidik/kependidikan dengan sopan dan keramahtamahan, kepala sekolah memberikan kemudahan kepada Tenaga Pendidik/kependidikan dalam memberikan pelayanan, kepala sekolah memberikan kenyamanan dalam melayani Tenaga Pendidik/kependidikan, kepala sekolah menerima dan mempertimbangkan saran yang diberikan Tenaga Pendidik/ kependidikan, kepala sekolah melibatkan Tenaga Pendidik/ kependidikandalam menyusun program sekolah, kepala sekolah melibatkan Tenaga Pendidik/ kependidikan dalam membuat kebijakan sekolah, tenaga Pendidik/ kependidikan merasa puas ketika berurusan dengan kepala sekolah, kepala sekolah berkomunikasi dengan baik dengan Tenaga Pendidik/kependidikan.

Berdasarkan hasil penelitian yang penulis dapatkan bahwasanya Pelayanan Kepala Sekolah Terhadap Tenaga Pendidik di Sekolah Dasar Negeri 01 Benteng Hulu Kecamatan Mempura Kabupaten Siak dengan porsentase ( 63.35) dengan kategori "mampu".
\end{abstract}

Kata kunci : Pelayanan Kepala Sekolah, dan Tenaga Pendidik 


\section{A. Pendahuluan}

Sekolah adalah lembaga yang bersifat kompleks dan unik, bersifat kompleks karena sekolah sebagai organisasi didalamnya terdapat berbagai dimensi yang satu sama lain saling berkaitan dan saling menentukan, sedangkan sifat unik menunjukkan bahwa sekolah sebagai organisasi memiliki ciriciri tertentu yang tidak dimiliki oleh organisasi-organisasi lain, ciri-ciri yang menempatkan sekolah memiliki karakter tersendiri dimana terjadi proses belajar mengajar tempat terselenggaranya pembudayaan kehidupan umat manusia. Karena sifatnya yang kompleks dan unik tersebutlah sekolah sebagai organisasi memerlukan tingkat koordinasi yang tinggi.

Keberhasilan sekolah adalah keberhasilan kepala sekolah. Kepala sekolah yang berhasil apabila mereka memahami keberadaan sekolah sebagai organisasi yang kompleks dan unik serta mampu melaksanakan peranan kepala sekolah sebagai seseorang yang diberi tanggungjawab untuk memimpin sekolah. ${ }^{1}$

Kepemimpinan kepala sekolah merupakan salah satu faktor yang dapat mendorong sekolah untuk dapat mewujudkan visi, misi tujuan dan sasaran sekolah melalui program-program yang dilaksanakan secara terencana dan bertahap. Oleh karena itu, kepala sekolah dituntut terampil dalam memimpin agar mampu mengambil keputusan dan prakarsa yang tepat untuk meningkatkan mutu sekolah. ${ }^{2}$

Kepala sekolah memiliki berbagai potensi yang dapat di kembangkan secara optimal, setiap kepala sekolah harus

1 Wahjosumidjo,Kepemimpinan Kepala Sekolah ; tinjauan teoritis dan permasalahannya. Jakarta, Raja Grapindo Persada, 1995, Hal. 81

E. Mulyasa, Kurikulum Berbasis Kompetensi, Bandung, Remaja Rosda Karya, 2002, hal. 182 memiliki perhatian yang cukup tinggi terhadap peningkatan kualitas pendidikan di sekolah. Perhatian tersebut harus ditunujukkan dalam kemauan dan kemampuan untuk mengembangkan diri dan sekolahnya secara optimal. ${ }^{3}$ Dan juga kepala sekolah akan memerankan fungsi memimpin sekolahnya, termasuk dalam kerangka strategis dan arah mengembangkan dan mengoptimalkan rencana perbaikan sekolah mengukur dan melaporkan kemajuan yang di capai. ${ }^{4}$

Dari uraian diatas jelaslah bahwa kepala sekolah memegang peranan penting dalam perkembangan sekolah. Oleh karena itu ia harus memiliki jiwa kepemimpinan/ manajerial untuk mengatur para guru, pegawai tata usaha, dan pegawai sekolah lainnya. Dalam hal ini, kepala sekolah tidak hanya mengatur para guru saja, melainkan juga ketata usahaan sekolah, siswa, hubungan sekolah dengan masyarakat dan orang tua siswa. Tercapai tidaknya tujuan sekolah sepenuhnya bergantung pada kebijaksanaan yang diterapkan kepala sekolah terhadap seluruh Tenaga Pendidik/ Kependidikan sekolah. ${ }^{5}$

Kepala sekolah merupakan salah satu kekuatan efektif dalam pengelolaan sekolah yang berperan bertanggung jawab dalam menghadapi perubahan agar para guru, staf dan siswa menyadari akan tujuan sekolah yang akan ditetapkan, dengan kesadaran tersebut para guru, staf dan siswa dengan enuh semangat melaksanakan tugas masing-masing dalam mencapai tujuan sekolah. Dengan demikian secara sederhana kepala sekolah dapat didefenisikan sebagai seorang tenaga fungsional guru yang diberi tugas

${ }^{3}$ E. Mulyasa, Menjadi Kepala Sekolah Yang Profesional. Bandung, Remaja Rosda Karya,2006, hal 70

${ }^{4}$ Sudarwan Danim, Visi Baru

Manajemen Sekolah, Bumi aksara, 2006, hal. 211

5 Yusak Burhanuddin, Administrasi Pendidikan. Bandung, Pustaka Setra,1998, Hal 119 
untuk memimpin suatu sekolah dimana diselenggarakan proses belajar mengajar, atau tempat dimana terjadi interaksi antara guru yang memberi pelajaran dan murid yang menerima pelajaran.

Kepala sekolah adalah orang yang ditunjuk sebagai pimpinan disuatu lembaga pendidikan. Kepala sekolah berperan penting dalam kesuksesan disuatu lembaga pendidikan dan bertanggung jawab dalam menghadapi perubahan staf, guru dan siswa, disamping demi tercapainya visi dan misi disuatu lembaga pendidikan tidak terlepas dari peran aktif Tenaga pendidik/ Kependidikan sekolah, kepala sekolah harus melibatkan Tenaga Pendidik yang ada di Sekolah Dasar Negeri 01 Benteng Hulu Kecamatan Mempura Kabupaten Siak tersebut, karena kerja sama antara kepala madrasah dengan Tenaga Pendidik yang baik merupakan kesuksesan disuatu lembaga.

Layanan adalah tindakan yang sifat dan arahnya menuju kepada kondisi yang lebih baik yang membahagiakan bagi pihak yang dilayani. Siapapun juga yag hendak atau bahkan yang sedang dilayani seseorang atau subjek lainnya pastilah berkehendak agar orang atau subjek yang dilayaninya itu mengarah atau menjadi lebih baik/ bahagia daripada kondisinya sebelumnya. Dengan kata lain orang yang sedang dilayani memiliki profek untuk menjadi lebih baik, lebih bahagia.

Hubungan kepala Sekolah dengan Tenaga Pendidik merupakan bentuk komunikasi ekstren yang dilakukan atas dasar tanggung jawab dan tujuan. Secara umum kepala Sekolah Dasar Negeri 01 Benteng Hulu Kecamatan Mempura Kabupaten Siak dengan Tenaga Pendidiknya memiliki tujuan yang hendak dicapai yakni berupa peningkatan mutu pendidikan, sehingga pada gilirannya semua

Pendidik/KependidikanSekolah Tenaga akan merasakan dampak langsung dari kemajuan Sekolah tersebut.

Beberpa faktor pendukung pelayanan kepala Sekolah Dasar Negeri 01 Benteng Hulu Kecamatan Mempura Kabupaten Siak terhadap stakeholder antara lain: a) kepemimpinan kepala sekolah, b)manajemen sekolah yang terbuka, c) tersedianya waktu yang cukup dalam memberikan pelayanan, d) dan adanya data sekolah yang memadai sehingga memudahkan dalam memberikan informasi. $^{6}$

Pelayanan adalah kegiatan yang dilakukan seseorang untuk membantu, mengurus, menyelesaikan keperluan, kebutuhan seseorang atau kelompok orang karena itu berdasarkan studi pendahuluan penulis menemukan kejala-gejala sebagai berikut :

1. Adanya Tenaga Pendidik / kependidikan yang belum puas dengan layanan kepala Sekolah Dasar Negeri 01 Benteng Hulu Kecamatan Mempura Kabupaten Siak.

2. Adanya Tenaga Pendidik / kependidikan yang tidak mengetahui tentang informasi-informasi penting dari kepala sekolah.

3. Masing kurangnya komunikasi yang baik antara kepala sekolah dengan Tenaga Pendidik kependidikansekolah.

4. Tenaga Pendidik / kependidikan sekolah jarang melibatkan dalam mengambil kebijakan sekolah.

\section{B. Pelayanan}

\section{Pengertian Pelayanan}

Pelayanan adalah suatu kegiatan untuk melayani, membantu dan mengurusi keperluan individu atau kelompok orang. Program pelayanan terhadap personil/ stakeholder bertitik tolak dari konsep
${ }^{6}$ SyaifulSagala,

ManajemenStrategikdalamPeningkatanMutuPendi dikan. Bandung, Alfabeta, 2007, hal, 236 
kepedulian kepada konsumen terus dikembangkan sedemikian rupa, sehingga sekarang ini program pelayanan telah menjadi suatu diantara alat utama dalam melaksanakan strategi dalam memenangkan persaingan. Sebagai abdi masyarakat maka kepala madrasah harus memberikan suatu pelayanan yang baik kepada personilnya. Pelayanan merupakan rangkaian pelaksanaan pelayanan pegawai sebagai aparatur Negara atau abdi masyarakat dalam melayani kepentingan umum. $^{7}$

Dalam kegiatan pelayanan terdapat beberapa macam pelayanan antara lain sebagai berikut :

a. Pelayanan konsultatif, salah satu fungsi dari lembaga pendidikan adalah memberikan pelayanan konsultatif bagi personil, pelayanan yang dimaksudkan agar mereka yang menerima pelayanan dapat memecahkan permasalahan yang mereka hadapi.

b. Pelayanan administrasi, pelayanan ini mencakup penelitian dan statistik, perencanaan sarana sekolah, inerpretasi tentang undang-undang pendidikan, sertifikasi, pembinaan hubungan masyarakat dan bantuan mengatasi permasalahan dibidang pendidikan.

c. Pelayanan pengajaran, guru dan administrasi sekolah adalah sumber informasi yag penting bagi lembaga pendidikan dalam rangka memajukan pendidikan. Bagi lembaga pelayanan ini merupakan pelayanan kepemimpinan lembaga untuk mengatasi permasalahan pendidikan. $^{8}$

\section{Karekteristik Pelayanan}

Kepala Madrasah harus dapat memberikan pelayanan terbaik bagi

\footnotetext{
${ }^{7}$ SyaifulSagala, 2007, Op. Cit., hal.238

${ }^{8}$ Wastysoemanto, Pendidikan Profesibagi Pemimpin Pendidikan. Surabaya, Effest printing, 1990, hal. 74
}

personilnya yang mempunyai kepentingan terhadap kemajuan sekolah. Dengan demikian dalam memberikan pelayanan terdapat beberapa karakteristik dan ciriciri pelayanan terbaik antara lain :

1. Kepastian waktu pelayanan adalah merupakan waktu yag diharapkan berkaitan dengan waktu proses atau penyelesaian, pengiriman, penyerahan dan menanggapi keluhan.

2. Kesopanan dan keramahtamahan dalam memberikan pelayanan, kepala sekolah yang berintegrasi langsung dengan personilnya harus dapat memberikan sentuhan pribadi yang menyenangkan dengan bersikap ramah, ceria, dan bertutur kata yang sopan.

3. Tanggung jawab merupakan bertanggung jawab dalam menerima pesan atau permintaan atau penanganan keluhan personilnya.

4. Kelengkapan pelayanan menyangkut lingkup pelayanan, ketersediaan sarana pendukung.

5. Kemudahan mendapatkan pelayanan berkaitan dengan banyaknya fasilitas yang mendukung.

6. Kenyamanan dalam memperoleh layanan berkaitan dengan ruang tunggu, ketersediaan data dan informasi. ${ }^{9}$

\section{Kepala Sekolah Sebagai Pelayanan Publik}

Kepala sekolah pada hakikatnya adalah sebagai pelayanan pendidikan kepada semua personil ayang ada disekolah. Kepala sekolah tidak diadakan untuk melayani dirinya sendiri, tetapi melayani semua guru-guru dan staf yang ada di lembaga tersebut serta menciptakan kondisi yang memungkinkan setiap anggota masyarakat sekolah dapat

${ }^{9}$ Barata, Dasar-Dasar Pelayanan

Prima.Jakarta, RinekaCipta, 2003,hal. 43 
mengembangkan kemampuan dan
kreatifitasnya melalui proses pendidikan. Pelayanan publik oleh kepala sekolah merupakan salah satu dari perwujudan dari fungsi sekolah sebagai "public good". pelayanan umum ini diartikan sebagai segala bentuk kegiatan pelayanan umum yang dilaksanakan oleh kepala sekolah dalam bentuk pelayanan belajar dan keterampilan dalam pemenuhan kebutuhan personilnya agar proses belajar mengajar bisa terjadi lebih baik.

Pelayanan publik oleh kepala sekolah dapat diartikan sebagai pemberian layanan keperluan orang atau personil madrasah yang mempunyai kewenangan terhadap kemajuan madrasah sesuai dengan aturan pokok dan tata cara yang ditetapkan. Sementara itu dipihak lain, kondisi stakeholders yang telah terjadi suatu perkembangan yang sangat dinamis. Oleh karena itu pelayanan kepala sekolah kepada personilnya juga mengacu pada perkembangan stakeholders itu sendiri baik dalam skala lingkup sekolah maupun diluar sekolah. Memberikan pelayanan yang terbaik salah satu upaya menumbuhkan kepercayaan masyarakat.

Kepala sekolah mempunyai tanggung jawab yang besar terhadap perkembangan sekolah, karena ia merupkan kekuatan inti atau kekuatan sentral dalam proses belajar mengajar di sekolah. layanan kepala sekolah sebagai manajer pendidikan di sekolah akan mempengaruhi kualitas sekolah dalam pendidikan.

Kepala sekolah juga berperan penting untuk menjalankan kepemimpinan untuk memajukan pengajaran. Konsep sekolah sebagai pusat pengembangan kurikulum menambah dimensi baru terhadap fungsi kepemimpinan kepala sekolah. Tugas-tugas untuk memajukan pengajaran adalah banyak dan macammacam. Berikut ini tugas-tugas pokok pemimpin pendidikan antara lain adalah (1) membantu orang-orang dalam masyarakat sekolah merumuskan tujuantujuan pendidikan, (2) memudahkan proses belajar mengajar, mengembangkan efektifitas mengajar, (3) membentuk unit organisasi yang produktif, menciptakan iklim dimana kepemimpinan dapat tumbuh dan berkembang, (5) memberikan sumber-sumber yang memadai untuk pengajaran yang efektif.

Kepala sekolah berperan pula untuk mengembangkan kepemimpinan staf sekolah. Ia senantiasa harus bekerja sama staf dalam pemecahan masalah maupun pembuatan keputusan melalui hubungan tatap muka individual dan kelompok. Diantara guru-guru dapat dipilih wakil-wakil untuk duduk dalam dewan penasehat sekolah. Dari dewan penasehat ini diperlukan sumbangansumbangan terhadap sekolah untuk memajukan mutu sekolah dan pendidikan.

Dalam memajukan sekolah, seorang kepala sekolah harus mempunyai karekteristik jabatan sebagai manejer pada umumnya yang harus memiliki tolok ukur tertentu dalam menjalankan peranannya sebagai pimpinan yaitu: (1) manejer mampu bekerja dibawah tekanan terus menerus dalam berbagai tantangan situasi atau kondisi tugas dan tanggungjawab serta kemungkinan resiko tertentu yang mungkin dihadapinya, (2) lebih banyak menggunakan komunikasi bahasa lisan sebagai media penyampaian pesan dan informasi sehingga terdapat arus instruksi dari atas kebawah atau dari bawah keatas demi terpeliharanya saling berpengertian dan kepercayaan bagi kedua belah pihak dalam menjalankan fungsinya masingmasing, (3) memberikan motivasi, menumbuhkan inspirasi, semangat dan dorongan kepada pihak lain untuk bertindak sesuai dengan apa yang direncanakan (pre determine objective), (4) menyeleksi dan mengembangkan bawahan nya melalui sistem pelatihan dan pendidsikan yang terarah dan terencana serta rasional, (5) dalam praktiknya, sisi 
seni dalam manajemen lebih menonjol dari pada sisi ilmiahnya, namun tetap memperhatikan segi profesionalismenya dalam melaksanakan fungsi dan peranannya masing-masing, baik bawahan maupun atasan. ${ }^{10}$

Kepuasan personil kepada pelayanan kepala sekolah akan dapat meningkatkan citra sekolah yang baik bagi sekolah, dengan dukungan dan kepercayaan personil kepada kepala sekolah sebagai pimpinan atau atasan dan menjadikan madrasah itu semakin bergengsi.

Pelayanan yang terbaik atau pelayanan prima sangat diperlukan disetiap sekolah agar murid-murid betah dan nyaman di sekolah sehingga bisa belajar dengan optimal. Hal ini mendorong kepala sekolah memberikan layanan pendidikan yang lebih profesional, efektif, efesien, sederhana, transparan, terbuka, tepat waktu respontif dan adaftif sebagai upaya sekolah memenuhi kualitas yang dibutuhkan masyarakat.

Arah kebijakan kepala sekolah menyelenggarakan pendidikan sesuai standar yang dipersyaratkan dengan manajemen yang efektif dan efesien yang memungkinkan setiap anggota personil mengembangkan kemampuan dan kreatifitasnya untuk mengatur dan menentukan masa depannya.

Kepala sekolah juga berperan aktif sebagai supervisor yang memberikan kebebasan kepada guru-guru untuk mengembangkan potensi dan daya kreasi mereka dengan rasa tanggung jawab, dengan memberikan pelayanan dan bimbingan kepada guru-guru untuk meningkatkan efektifitas proses belajar mengajar.

Organisasi profesi administrasi pendidikan bergerak memberikan layanan pendidikan, guna meningkatkan kualitas

\footnotetext{
${ }^{10}$ RosadiRuslan, Manajemen Public Relations dan Media komunikasi. Jakarta, Raja GrapindoPersada, 2007,hal 4-5
}

kepemimpinan pendidikan. Semua anggota organisasi profesi administrasi pendidikan diharapkan dapat :

1. Bekerja secara kooeratif untuk meamjukan program pendidikan.

2. Mengerti dengan jelas dinamika dan dimensi-dimensi kepemimpinan pendidikan.

3. Berpartisipasi dalam kegiatan profesional bertambah dalam jabatan.

4. Mengembangkan administrasi pendidikan sebagai suatu profesional.

5. Mengembangkan kode etik profesi administrasi pendidikan. ${ }^{11}$

\section{Kepala Sekolah sebagai innovator}

Dalam Rangka melakukan peran dan fungsinya sebagai innovator, kepala sekolah harus memiliki strategi yang tepat untuk menjalin hubungan yang harmonis dengan lingkungan mencari gagasan baru, mengintegrasikan setiap kegiatan, memberikan teladan kepada seluruh tenaga kependidikan disekolah, dan mengembangkan model-model pembelajaran yang innovatif.

Kepala sekolah sebagai innovator akan tercermin dari cara-cara ia melakukan pekerjaannya secara konstruktif, kreatif, delegatif, integratif, rasional dan objektif, pragmatis, keteladanan,disiplin, serta adabtabel dan fleksibel. ${ }^{12}$

a. Konstruktif adalah bahwa dalam meningkatkan profesionalisme tenaga kependidikan disekolah, kepala sekolah harus berusaha mendorong dan membina setiap tenaga kependidikan agar dapat berkembang secara optimal dalam melakukan tugas-tugas yang

${ }^{11}$ AryGunawan, AdministrasiPendidikan. Yogyakarta, AsdiMahastya, 2002,hal 186

${ }^{12}$ E. Mulyasa, Menjadi Kepala Sekolah yang Profesional. Bandung,RemajaRosda karya, 2007,hal. 118 
diembankan kepada masingmasing tenaga kependidikan.

b. Kreatif yaitu bahwa dalam meningkatkan profesionalisme tenaga kependidikan disekolah, kepala sekolah harus berusaha mencari gagasan dan cara-cara baru dalam melaksanakan tugasnya. Hal ini dilakukan agar para tenaga kependidikan dapat memahami apa-apa yang disampaika oleh kepala sekolah sebagai pimpinan, sehingga dapat mencapai tujuan sesuai dengan visi dan misi sekolah.

c. Delegatif adalah bahwa dalam meningkatkan profesionalisme tenaga kependidikan disekolah, kepala sekolah harus berupaya mendelegasikan tugas kepada tenaga kependidikan sesuai dengan diskripsi tugas, jabatan serta kemampuan masing-masing.

d. Integratif adalah bahwa dalam meningkatkan profesionalisme tenaga kependidikan disekolah, kepala sekolah harus berusaha mengintegrasikan semua kegiatan sehingga dapat menghasilkan sinergi untuk mencapai tujuan sekolah secara efektif, efesien dan produktif.

e. Rasional dan objektif yaitu bahwa dalam meningkatkan profesionalisme tenaga kependidikan disekolah, kepala sekolah harus berusaha bertindak berdasarkan pertimbangan rasio dan objektif.

f. Pragmatis adalah bahwa dalam meningkatkan profesionalisme tenaga kependidikan disekolah, kepala sekolah harus berusaha menetapkan kegiatan atau target berdasarkan kondisi dan kemampuan nyata yang dimiliki oleh setiap tenaga kependidikan, serta kemampuan yang dimiliki sekolah.

g. Keteladanan yaitu bahwa dalam meningkatkan profesionalisme tenaga kependidikan disekolah, kepala sekolah harus berusaha memberikan teladan dan contoh yang baik.

h. Adaptabel dan fleksibel yaitu bahwa dalam meningkatkan profesionalisme tenaga kependidikan disekolah, kepala sekolah harus mampu beradaptasi dan fleksibel dalam menghadapi situasi baru, serta berusaha menciptakan situasi kerja yang menyenangkan dan memudahkan para tenaga kependidikan untuk beradaptasi dalam melaksanakan tugasnya. ${ }^{13}$

\section{Kepala Sekolah Sebagai administrator \\ Kepala sekolah sebagai} administrator di sekolah harus dapat melaksanakan fungsinya sebagai manejer ( Pengelola) agar tujuan yang telah dirumuskan bisa terealisasi secara efektif. Fungsi-fungsi tersebut merupakan proses yang harus dilaksanakan oleh semua pihak yang terlibat di dalam sebuah organisasi. Dengan fungsi ini juga dapat menentukan berhasil atau tidaknya kinerja kepala sekolah sebagai administrator yang mengelola sekolah tersebut. Adapun fungsi-fungsi tersebut adalah:

1) Perencanaan ( Palnning)

Perencanaan merupakan langkah pertama yang harus benarbenar diperhatikan oleh manejer atau pengelola pendidikan. Sebab perencanaan yang meliputi penentuan tujuan, sasaran dan target pendidikan harus didasarkan 
pada situasi dan kondisi sumber daya yang dimiliki.

2) Pengorganisasian ( Organizing)

Pengorganisasian dapat diartikan sebagai penetapan struktur peran-peran melalui penentuan aktifitas-aktifitas yang dibutuhkan untuk mencapai tujuan bersama dengan bagian-bagian pengelompokkan aktifitas-aktifitas, penugasan kelompok, aktifitas kepada manejer-manejer, pendelegasian wewenang dan informasi horizontal maupun vertikal dalam struktur organisasi.

3) Penggerak (aktuating)

Penggerak adalah penempatan semua anggota dari sebuah kelompok agar bekerja secara sadar untuk mencapai tujuan yang telah ditetapkan sesuai perencanaan dan pola organisasi. Penggerak dalam pendidikan merupakan suatu upaya untuk memberikan arahan, bimbingan dan dorongan kepada sumber daya manusia dari personil yang ada dalam sebuah organisasi agar dapat menjalankan tugasnya dengan kesadaran yang tinggi.

4) Pengarahan

Pengarahan adalah kegiatan membimbing dengan jalan memberikan perintah, mendorong semangat kerja, menegakkan disiplin, memberikan berbagai usaha lainnya agar mereka dalam melakukan pekerjaan mengikuti arah yang ditetapkan dalam petunjuk, peraturan atau pedoman yang telah ditetapkan.

5) Koordinasi

Koordinasi adalah kegiatan menghubungkan orang-orang dan tugas-tugas sehingga terjalin kesatuan atau kecerdasan keputusan, kebijaksanaan, tindakan, langkah, sikap serta tercegah dari timbulnya pertentangan, kekacauan, kekosongan tindakan.

6) Pengawasan

Pengawasan adalah tindakan atau kegiatan usaha agar pelaksanaan kegiatan serta hasil kerja sesuai dengan rencana, perintah, petunjuk atau ketentuan ketentuan lainnya yang telah ditetapkan. ${ }^{14}$

\section{Faktor- faktor yang mempengaruhi pelayanan kepala sekolah terhadap Tenaga pendidik/kependidikan.}

Dalam memimpin lembaga pendidikan melaksanakan fungsi sebagai seorang kepala sekolah ia dipengaruhi oleh beberapa faktor secara garis besar ada 3 faktor yang mempengaruhi pelayanan kepala sekolah terhadap personilnya yaitu sifat-sifat yang dimiliki kepala sekolah, perilaku atau fungsi pemimpin terhadap kelompok yang dipimpinnya dan situasi intern dan ekstern lembaga yang bersangkutan. faktor yang paling dominan yang dipengaruhi perilaku seorang pemimpin adalah :

1. Keahlian dan pengetahuan, maksudnya latar belakang pendidikan dan ijazah yang dimiliki sesuai atau tidak dengan tugas kepemimpinan itu yang terjadi tanggung jawabnya.

2. Jenis pekerjaan atau lembaga tempat pemimpin melaksanakan tugas.

3. Sifat-sifat kepribadian pemimpin.

4. Sifat-sifat kepribadian pengikut kelompok orang yang dipimpinnya. Sanksi-sanksi yang ditangani pemimpin. ${ }^{15}$

\section{Tujuan Pelayanan}

${ }^{14}$ H. M. Daryanto, Administrasi pendidikan, Jakrta, Rineka Cipta, 2006, hal

${ }^{15}$ Ngalim Purwanto, administrasi dan Supervisi Pendidikan. Bandung, Remaja Rosda Karya, hal. 103 
Pelayanan pada hakekatnya bertujuan untuk meningkatkan mutu dan produktivitas pelaksanaan tugas, pekerjaan dan fungsi instansi pemerintah maupun swasta dibidang pelayanan umum, mendorong upaya mengefektifkan sistem dan tata laksana pelayanan, sehingga pelayanan dapat diselenggarakan secara lebih berdaya dan berhasil guna, serta mendorong tumbuhnya kreatifitas dan peran serta stakeholders maupun masyarakat dalam pembangunan untuk meningkatkan kesejahteraan masyarakat luas. Adapun tujuan dari pelayanan adalah sebagai berikut :

a. Menimbulkan kepercayaan dan kepuasan terhadap pelanggan / personil sekolah.

b. Menjaga agara stakeholders sekolah merasa dipentingkan dan diperhatikan segala keluahan dan keinginannya yang sesuai dengan peraturan yang ada.

\section{Tenaga Pendidik/kependidikan}

Guru merupakansuatukomponen yang sangat menentukan terhadap kelancaran proses belajar mengajar di lingkungan sekolah dan memegang peranan besar atas keberhasilan dalam pembelajaran.

Tenaga kependidikan menurut PP nomor 38 tahun 1992 pasal 1 adalah anggota masyarakat yang mengabdikan diri secara langsung dalam penyelenggaraan pendidikan. Lebih lanjut dalam pasal 3 dinyatakan:

B. Tenaga kependidikan terdiri dari atas tenaga pendidik, pengelola satuan pendidikan, penilik, pengawas, peneliti dan pengembangan di bidang pendidikan, pustakawan, laboran, teknisi sumber belajar, dan pengajar.

C. Tenaga pendidik terdiri atas pembimbing, pengajar, dan pelatih.

D. Pengelola satuan pendidikan terdiri atas kepala sekolah, direktur, ketua, rector dan pimpinan satuan pendidikan luar sekolah.

Padaprisipnya yang dimaksud personel di sini ialah orang-orang yang melaksanakan sesuatu tugas untuk mencapai tujuan. Personel di sekolah meliputi unsur guru yang disebut tenaga edukatif dan unsure karyawan yang disebut tenga administratif. Secara terperinci dapat disebutkan keseluruhan personel sekolah adalah: kepala sekolah, guru, pegawai tatausaha, dan pesuruh/penjaga sekolah.

Personal ialah semua anggota organisasi yang bekerja untuk kepentingan organisasi yaitu untuk mencapai tujuan yang sudah ditentukan. Dalam tiap kelompok personalia perlu pembagian tugas dan tanggungjawab serta hubungan kerja yang jelas. Seorang Kepala Sekolah dapat dibantu oleh seorang atau beberapa orang wakil kepala yang mengkoordinasikan urusan kurikulum atau kegiatan belajar mengajar, urusan kemurid dan, urusan sarana prasarana pendidikan, urusan hubungan sekolah dan masyarakat, dan sebagainya. Kelompok personalia non edukatif dipimpin oleh Kepala Tata Usaha, yang mempunyai tugas dan tanggungjawab serta hubungan kerja tersendiri pula. Tugas ini disesuaikan dengan luas lingkup pekerjaan dan keadaan personalianya.

Pada sekolah dasar, sampai saat ini personalia edukatif terdiri atas Guru Kelas, Guru Agama dan Guru Olah raga. Personalia non edukatif terdiri dari pesuruh dan penjaga sekolah. Di sekolah dasar yang terpencil sering kali personalia ini tidak ada. Demikian tidak ada wakil kepala sekolah dan kepala tatausaha di sekolah dasar. Tugas-tugas mereka seringkali dirangkap oleh Kepala Sekolah atau Guru.

Personel merupakan seluruh proses kegiatan yang direncanakan dan diusahakan secara sengaja dan bersungguh-sungguh serta pembinaan 
secara kontinu para pegawai di sekolah, sehingga mereka dapat membantu/menunjang kegitan-kegiatan sekolah (khususnya PBM) secara efektif dan efisien demi tercapainya tujuan pendidikan yang telah ditetapkan. Para personel harus diadministrasikan/dikelola dengan baik agar mereka senantiasa aktif dalam menjalankan tugasnya sehari-hari

Dalam Undang-undang No 20 tahun 2003 tentang Sistem Pendidikan Nasional pada pasal 39 ayat 2 berbunyi : " pendidik merupakan tenaga professional yang bertugas merencanakan dan melaksanakan proses pembelajaran, menilai hasil pembelajaran, melakukan pembimbingan dan pelatihan, serta melakukan penelitian dan pegabdian kepada masyarakat, terutama bagi pendidik pada perguruan tinggi". ${ }^{16}$

\section{Metode Penelitian}

\section{Jenis Penelitian}

Untuk menemukan pelayanan kepala sekolah terhadap tenaga pendidik di sekolah Dasar Negeri 01 Benteng Hulu Kecamatan Mempura Kabupaten Siak, maka digunakan jenis penelitian deskripsi Kualitatif.

\section{Waktu dan Lokasi Penelitian}

Penelitian akan dilakukan setelah waktu penelitian dilapangan. Lokasi penelitian ini adalah Sekolah Dasar Negeri 01 Benteng Hulu Kecamatan Mempura Kabupaten Siak. Waktu penelitian dari bulan Agustus sampai Desember 2015.

\section{Teknik Pengumpulan Data}

a. Angket

b. Observasi

c. Dokumentasi

Selanjutnya data yang bersifat

Kualitatif yang berwujud angka-angka digambarkan dengan persentase, lalu ditafsirkan kedata yang bersifat kualitatif yang digambarkan dengan kata-kata atau kalimat.

$$
\text { Denganrumus; } \mathrm{P}=\frac{\mathrm{F} \times}{\mathrm{N}} 100
$$

Sedangkan untuk data penelitian yang diklasifikasikan atau dikategorikan kuantitatif maka data yang didasarkan atas konsep yang dioperasionalkan disimpulkan dalam bentuk skala nominal dengan ukuran persentase sebagai berikut:

a. $0 \%-20 \%=$ Sangat tidak mampu

b. $21 \%-40 \%=$ Tidak mampu

c. $41 \%-60 \%=$ Cukup mampu

d. $61 \%-80 \%=\mathrm{Mampu}$

e. $81 \%-100 \%=$ Sangat $\operatorname{mampu}^{17}$

\section{E. Penyajian Data}

Fakta kajian dalam penelitian ini adalah tentang Pelayanan Kepala Sekolah Terhadap Tenaga Pendidik.Tujuan dari penelitian ini adalah untuk mendapatkan data guna untuk mengetahui sejauh mana Pelayanan Kepala Sekolah Terhadap Tenaga Pendidikdalam memimpin dan mengelola di Sekolah Dasar Negeri 01 Benteng Hulu Kecamatan Mempura Kabupaten Siak. dibawah kepemimpinannya.

Sewaktu mengumpulkan data di lapangan, penulis menggunakan beberapa teknik yaitu wawancara yang penulis jadikan sebagai metode pokok untuk memperoleh data yang ditujukan kepada kepala Sekolah Dasar dan juga guru.Sedangkan untuk mencari data pendukung penulis menggunakan angket yang berjumlah 10 eksemplar yang disebarkan kepada para guru yang dijadikan sebagai data pendukung untuk memperoleh data tentang Pelayanan Kepala Sekolah Terhadap Tenaga Pendidikdi Sekolah

\footnotetext{
${ }^{16}$ Undang-undang No 20 Tahun 2003 tentangSistemPendidikanNasional
} 
Dasar Negeri 01 Benteng Hulu Kecamatan Mempura Kabupaten Siak.Begitu juga dengan metode dokumentasi penulis jadikan sebagai upaya untuk mendapatkan data-data pendukung tentang faktor-faktor yang mendukung Pelayanan Kepala Sekolah Terhadap Tenaga Pendidik.

Data yang telah terkumpul melalui wawancara, penulis sajikan dalam bentuk narasi kemudian data dari angket, penulis sajikan dalam bentuk table dan prosentase. Dari uraian yang telah disajikan, supaya pembaca mudah untuk memahami table tersebut, maka penulis gunakan symbol F ( Frekwensi) dan $\mathrm{P}$ (Prosentase). Adapun data yang bersifat kualitatif dijadikan data kuantitatif dan klasifikasi yang digunakan dalam penelitian ini adalah;

\section{Tabel I}

Rekapitulasi Jawaban Angket Tentang Pelayanan Kepala Sekolah Terhadap

Tenaga Pendidik diSekolah Dasar Negeri 01 Benteng Hulu Kecamatan Mempura Kabupaten Siak

\begin{tabular}{|c|c|c|c|c|c|c|c|c|}
\hline \multirow{3}{*}{ No } & \multicolumn{6}{|c|}{ Alternatif Jawaban } & \multicolumn{2}{|c|}{ Jumlah } \\
\hline & \multicolumn{2}{|c|}{$\mathrm{A}$} & \multicolumn{2}{|c|}{$\mathrm{B}$} & \multicolumn{2}{|c|}{$\mathrm{C}$} & & \\
\hline & $\mathrm{F}$ & $\begin{array}{c}\mathrm{P} \\
(\%)\end{array}$ & $\mathrm{F}$ & $\begin{array}{c}\mathrm{P} \\
(\%)\end{array}$ & $\mathrm{F}$ & $\begin{array}{c}\mathrm{P} \\
(\%)\end{array}$ & $\begin{array}{r}F \\
P(c\end{array}$ & \\
\hline 1 & 15 & 50 & 12 & 40 & 3 & 10 & 30 & 100 \\
\hline 2 & 6 & 20 & 21 & 70 & 3 & 10 & 30 & 100 \\
\hline 3 & 6 & 20 & 12 & 40 & 12 & 40 & 30 & 100 \\
\hline 4 & 0 & 0 & 18 & 60 & 12 & 40 & 30 & 100 \\
\hline 5 & 0 & 0 & 15 & 50 & 15 & 50 & 30 & 100 \\
\hline 6 & 3 & 10 & 21 & 70 & 6 & 20 & 30 & 100 \\
\hline 7 & 6 & 20 & 21 & 70 & 3 & 10 & 30 & 100 \\
\hline 8 & 6 & 20 & 12 & 40 & 12 & 40 & 30 & 100 \\
\hline 9 & 3 & 10 & 18 & 60 & 9 & 30 & 30 & 100 \\
\hline 10 & 6 & 20 & 15 & 50 & 9 & 30 & 30 & 100 \\
\hline 11 & 21 & 70 & 6 & 20 & 3 & 10 & 30 & 100 \\
\hline 12 & 3 & 10 & 12 & 40 & 15 & 50 & 30 & 100 \\
\hline 13 & 3 & 10 & 15 & 50 & 12 & 40 & 30 & 100 \\
\hline 14 & 18 & 60 & 9 & 30 & 3 & 10 & 30 & 100 \\
\hline 15 & 9 & 30 & 9 & 30 & 12 & 40 & 30 & 100 \\
\hline 16 & 21 & 70 & 3 & 10 & 6 & 20 & 30 & 100 \\
\hline 17 & 3 & 10 & 12 & 40 & 15 & 50 & 30 & 100 \\
\hline 18 & 0 & 0 & 12 & 40 & 18 & 60 & 30 & 100 \\
\hline 19 & 3 & 10 & 27 & 90 & 0 & 0 & 30 & 100 \\
\hline 20 & 3 & 10 & 9 & 30 & 18 & 60 & 30 & 100 \\
\hline $\begin{array}{c}\text { Juml } \\
\text { ah }\end{array}$ & 135 & 450 & 283 & 910 & 196 & 620 & 30 & 100 \\
\hline
\end{tabular}

Analisa Data Tentang Pelayanan Kepala Sekolah Terhadap Tenaga Pendidik di Sekolah Dasar Negeri 01 Benteng Hulu Kecamatan Mempura Kabupaten Siak.

Data-data hasil observasi dan angket telah penulis sajikan pada bab IV diatas, penulis akan menganalisa data-data yang penulis sajikan tersebut,sehingga dapat dengan jelas hasil yang diperoleh dari penelitian tentang Pelayanan Kepala Sekolah Terhadap Tenaga Pendidik di Sekolah Dasar Negeri 01 Benteng Hulu Kecamatan Mempura Kabupaten Siak. 
Teknik analisa data yang penulis gunakan adalah teknik deskriftif kualitatif dengan persentase.Sesuai dengan kategori yang penulis tentukan yaitu sangat mampu, mampu, cukup mampu, tidak mampu, sangat tidak mampu. Maka, sebelum dilakukan kualifikasi, alternative jawaban terlebih dahulu diberi penskoran, yaitu ; alternative jawaban A diberi skor 3, untuk $\mathrm{B}$ di beri skor 2, dan untuk $\mathrm{C}$ diberi skor 1 .

Pada bab III di jelaskan bahwa teknik analisis data yang penulis gunakan dalam penelitian ini adalah deskriftif kualitatif dengan prosentase, dengan artian bahwa selain menggambarkan apa adanya serta menginterpretasikan frekuwensi juga memberi prosentase pada alternative jawaban angket. Hal ini dilakukan dengan cara;

1. Dijumlahkan dan dibandingkan dengan jumlah yang diharapkan untuk memperoleh prosentase

2. Dari prosentase yang diperoleh lalu ditafsirkan dengan bentuk kualitatif dengan ketentuan sebagai berikut:

a. Yang tergolong sangat mampu, apabila hasil prosentasenya mencapai antara: 81-100\%.

b. Yang tergolong mampu, yaitu apabila hasil prosentase mencapai antara: $61-80 \%$.

c. Yang tergolong cukup mampu, yaitu apabila hasil prosentase mencapai antara: 41-60\%.

d. Yang tergolong tidak mampu, yaitu apabila hasil prosentase mencapai antara $21-40 \%$

e. Yang tergolong sangat tidak mampu yaitu apabila hasil prosentase kurang dari $20 \%$.
Dalam mencapai prosentase tersebut penulis menggunakan rumus:

$\mathrm{P}=\frac{\mathrm{F}}{\mathrm{N}} \times 100 \%$

Berdasarkan dari rekapitulasi yang telah dipaparkan diatas, maka dapat dicari $\mathrm{F}$ dari masing-masing pilihan dengan terlebih dahulu memberikan skor pada masing-masing point yaitu:

Pilihan $\mathrm{A}=3$

Pilihan $\mathrm{B}=2$

Pilihan $\mathrm{C}=1$

Dengan demikian akan diperoleh skor F pada masingmasing pilihan yaitu:

Pilihan $A=135 \times 3=405$

Pilihan $\mathrm{B}=283 \times 2=566$

Pilihan $\mathrm{C}=\frac{196}{614} \times 1=\frac{196}{1167}$

Namun jumlah yang diharapkan adalah jumlah banyaknya alternative jawaban dikalikan dengan jumlah seluruh jawaban yaitu 614 X $3=1842$. untuk mendapatkan kualitas jawaban responden adalah total keseluruhan skor alternative jawaban-jawaban (1842), dibandingkan dengan jumlah yang diharapkan (1167) lalu dikalikan dengan $100 \%$ maka diperoleh hasil sebagai berikut:

$$
\begin{aligned}
P & =\frac{F}{N} \times 100 \% \\
& =\frac{1167}{1842} \times 100 \% \\
& =63,35
\end{aligned}
$$

Berdasarkan dari hasil prosentase rekapitulasi angket tersebut, maka dapat diperoleh gambaran bahwa Pelayanan Kepala Sekolah Terhadap Tenaga Pendidik di Sekolah Dasar Negeri 01 Benteng 

Hulu Kecamatan Mempura
Kabupaten Siak dengan mengacu pada kategori yang telah ditentukan sebelumnya bahwa prosentase dari hasil penelitian ini (63.35) berada pada kategori antara 61- $80 \%$.

Hal tersebut menunjukkan bahwa tingkat Pelayanan Kepala Sekolah Terhadap Tenaga Pendidik diSekolah Dasar Negeri 01 Benteng Hulu Kecamatan Mempura Kabupaten Siak tergolong “Mampu”.

\section{F. Daftar Pustaka}

Arikunto, Suharsimi,Prosedur Penelitian; Suatu Pendekatan Sistem, Jakarta: Rineka Cipta, 1998

Barata, Dasar-Dasar Pelayanan Prima, Jakarta; Rineka Cipta, 2003

Daryanto,H. M., Administrasi Pendidikan. Jakrta: Rineka Cipta, 2006

Faisal, Sanapiah, Penelitian Kualitatif: Dasar-Dasar dan Aplikasi, Malang: YAI, 1990

Gunawan, Ary,Administrasi Pendidikan. Yogyakarta: Asdi Mahastya, 2002

Kartini, Pengantar Metode Riset Sosial, Bandung; Mandar Maju, 1980

Koentjoroningrat,Metode Penelitian Masyarakat,Jakarta: Gramedia, 1993

Muda, Ahmad A.K., Kamus Lengkap Bahasa Indonesia. Jakarta: reality Publishen, 2006
Mulyasa, E, Kurikulum Berbasis Kompetensi, Bandung: Remaja Rosda Karya, 2002

,Menjadi Kepala Sekolah Yang

Profesional,Bandung: PT. Remaja Rosda Karya, 2006

, Menjadi Kepala Sekolah yang

Profesional, Bandung: Remaja

Rosdakarya, 2007

-Metode Penelitian Kualitatif;

Paradigma Baru Ilmu Komunikasi dan Ilmu,Sosial Lainnya, Bandung: Rosda Karya2002

Nasir, Moh,Metode Penelitian.Jakarta: Ghalia, 1988

Nata, Abudin,Filsafat Pendidikan Islam 1. Jakarta: Logos,Wacana, 1997

Prayitno, Wawasan Profesional Konseling. Padang: Universitas Negeri Pandang, 2009

Purwanto, Ngalim, Administrasi dan Supervisi Pendidikan. Bandung: Remaja Rosda Karya.

Ruslan, Rosadi,Manajemen Public Relations dan Media komunikasi. Jakarta: Raja Grapindo Persada, 2007

Ridwan, Sakala Pengukuran VariabelVariabel Penelitian. Bandung: Alfabeta, 2008

Sudarwan, Danim, Visi Baru Manajemen Sekolah. Bumi aksara. 2006

Sagala, Syaiful,Manajemen Strategik dalam Peningkatan Mutu Pendidikan. Bandung: Alfabeta, 2007 
Soemanto, Wasty,Pendidikan Profesi bagi Pemimpin Pendidikan.Surabaya: Effest printing, 1990

Suharsimi Arikunto, Prosedur Penelitian; Suatu Pendekatan Sistem, Jakarta;RinekaCipta, 1998.

Suhertian, Prosedur Penelitian Suatu Pendekatan raktis, Jakarta: Renika Cipta, 1991

Undang-undang No 20 Tahun 2003 tentang Sistem Pendidikan Nasional 